\title{
Analysing Properties of Asphalt Concrete Modified with Crumb Rubber Compare to Other Mixture
}

\author{
Abdallh. A. A. Lhwaint ${ }^{1}$, Mohmed Alshekh A. M. Hmade ${ }^{2}$, Ervina Ahyudanari ${ }^{3}$, Indrasurya \\ B.Mochtar ${ }^{4}$, Abrahem A Ali blash ${ }^{5}$, \\ Post Graduate Civil Engineering Programs Institue Teknologi Sepuluh Nopember(2016-2017), \\ kapmus ITS Sukolilo Surabaya 60111 Indonesia Telp: +62-31-5928797, Email: \\ Alhwaint@yahoo.com Email:mhmadi67@yahoo.com,Email:Ervina@ce.its.ac.id, \\ Email:indramochtar.mochtar@gmail.com Email:blash1985@gmail.com
}

\begin{abstract}
Several researchers have been undertake in finding alternative materials in order to be used as a modifier in asphalt mixture for the purpose of improving its properties. This research presents a study of laboratory evaluation on the performance of hot-mixed asphalt (HMA) using crumb rubber as an additive. It is noted that crumb rubber was identified to have potency as a modifier in HMA due to the elastic behavior exposed by the rubber particles, especially in reducing the rutting potential. This study fine crumb rubber Shred $(\mathbf{2 . 3 6}-\mathbf{0 . 8 5} \mathrm{mm})$ obtained by ambient-temperature grinding process from discarded truck tires, was used to modify asphalt concert. The fine crumb rubber with different contents, i.e. $2.5 \%, 5 \%, 7.5 \%$ and $10 \%$, was incorporated into the mixture by using dry and wet process method in differentent temperatures. The Marshal properties, Unconfined Compressive Strength (UCS), Indirect Tensile Strength test (ITS) and Indirect Tensile Strength Modulus (ITSM), Permeability were conducted. The result showed that marshal stability, Marshal Quotient, Voids in Mix (VIM) and Voids in mineral aggregate (VMA) decreased with the increasing crumb rubber modifier. However, Marshal Flow and Void filled with asphalt (VFWA) increased when crumb rubber modifier was increased. The crumb rubber asphalt mixture result indicated has increased amount of crumb rubber in asphalt concrete mixture will decrease the Marshall Stability and permeability test shows that asphalt concrete without crumb rubber lower than $\mathrm{AC}$ with crumb rubber strength compare to other mixture.
\end{abstract}

Keywords - Asphalt concrete Crumb Rubber modifier Marshall, ITS, ITSM, UCS, and Permeability Test.

\section{I.INTRODUCTION}

$\mathrm{R}$ oadways are important in our daily lives. A lot of monies are spent annually by governments on the construction and maintenance of roadways. It would greatly benefit to the Libyan economy. If we could extend the service life of the roads. In order to enhance pavement performance, it is essential to understand the materials involved in pavement construction. Therefore, crumb rubber could be an alternative material in improving the quality of hot mix asphalt. In the process, most of the steel wires and reinforcing fibers or fluff of the recycled tired are removed. The crumb rubber is often served and separated in categories based on gradation to meet the requirements of a particular application or agency. The purpose of this study is to find the optimum bitumen content in asphalt concrete modified with crumb rubber by marshal test and get the maximum amount of crumb rubber tire in modified asphalt concrete mixture. Most of the previous researches show a general trend about Marshall Mixes that the dry process of incorporating CRM into asphalt mixes reduced the rutting resistance while wet process of incorporating CRM into the mixes enhanced the rutting resistance[1].The dry process uses rubber as an aggregate. Typically, $2-3 \%$ rubber is preblended with the aggregates prior to charging the mixture with a pure asphalt binder [2].

The process of mixing the crumb rubber with the asphalt cement prior mixing to it with aggregates is known as the 'wet processes'. Whereas 'dry process' is referred to a method that first blends crumb rubber with hot aggregates prior to mixing it with asphalt binder which the end product called Rubber Modified Asphalt Concrete (RUMAC) mixes[3]. Development of Modified asphalt materials to improve the overall performance of pavements has been the focus of several research efforts made over the past few decades. Crumb rubber is the recycled rubber obtained by mechanical shearing or grinding of tires into small particles [4]. Waste rubber tires that cannot be processed for useful applications are numbered in the millions around the world. The buildup of old rubber tires in landfills is commonly considered a major threat to the environment, and it is unquestionably a burden on landfill space. The test results showed that asphalt mixtures with 
rubberized bitumen binders are characterized by high resistance to permanent deformations [5].

Most of the research conducted on CRM mixes is based on Marshall Mix designed [6]. Available literature does not offer uniform guidelines for the conditions of blending crumb rubber with asphalt cement. Performance of CRM was reported to be dependent on various factors such as source of crumb rubber, blending conditions, mixture variables, aggregate gradation, compaction method used. ${ }^{[11]}$ In this study to make comparison between the two types (without and with crumb rubber) of properties of the hot mix asphalt toward the Marshall properties to get Optimum Asphalt Content, Indirect Tensile Strength (ITS) at different test temperature $\left(30{ }^{\circ} \mathrm{C}, 40{ }^{\circ} \mathrm{C}\right.$ and $\left.60{ }^{\circ} \mathrm{C}\right)$ and Unconfined Compressive Strength (UCS) at 30 ${ }^{0} \mathrm{C}$, Indirect Tensile Strength Modulus (ITSM) at 40 ${ }^{0} \mathrm{C}$ and permeability Test. Thus, by conducting study on the CRM asphalt concrete mixes the performance can be evaluated whether a particular combination will yield improvements in the desired properties or vice versa. ${ }^{[5]}$

\section{II.THE METHOD RESEARCH}

This paper discusses the mix design of asphalt concrete modified with crumb rubber and several tests that will be conducted in achieving the objectives of the study. The laboratory works can be divided into several stages beginning with the aggregates preparation and distribution into different particle sizes through sieve analyses. Firstly, the quarry aggregates will be dried sieve and blended meeting the gradation limit. Washedsieve analysis that types of mixes will be modified with crumb rubber which is AC the laboratory works can be divided into several stages beginning with the aggregates preparation and distribution in to different particle sizes through sieve analyses. Washed-sieve analysis that will be referred determine the proportion of mineral filler content required in the aggregates gradation [7]. For this study, fine crumb rubber (grinding from truck tyres) will be added in a form of powder where the size will be between $0.6 \mathrm{~mm}$ to $0.3 \mathrm{~mm}$. The amount of crumb-rubber modifiers added to the mixes will be expressed in the percentage. For this study, fine crumb rubber (grinding from truck tyres) will be added in a form of powder where the size will be between $0.6 \mathrm{~mm}$ to $0.3 \mathrm{~mm}$. The amount of crumb-rubber modifiers added to the mixes will be expressed in the percentage. It generally occupies $60 \%$ to $75 \%$ of the concrete volume. Where fine aggregate is the aggregate whose size is less than $4.75 \mathrm{~mm}$, for example sand is used as fine aggregate in the preparation of concrete and cement mortar. Fine aggregates generally consist of natural sand or crushed stone with most particles passing through a 3/8-inch sieve.In this study, the laboratory works can be divided into three stages: The First Stage: make tests in the laboratory on the following mixtures materials such as:

Asphalt content $(5 \%, 5.5 \%, 6 \%, 6.5 \%, 7 \%)$.Coarse aggregat, Fine aggregat, to know the physical properties and the possibility of their use in the mixture.The Second Stage: make Marshall Tests.In the total of specimens 174 samples with compaton 75 times.In the laboratory on the following mixture (AC 60/70) without and with Crumb Rubber to know their Marshall properties to get OBC.The Third Stage: make UCS test at $30^{\circ} \mathrm{C}$, ITS test at $\left(30^{\circ} \mathrm{C}, 40^{\circ} \mathrm{C}, 60^{\circ} \mathrm{C}\right)$, Indirect Tensile Strength Modulus (ITSM) at $40{ }^{\circ} \mathrm{C}$ and Permeability Test. The objective of that is a comparing the results between Asphalt concrete (AC 60/70) and asphalt concrete modified with $(2.5 \%, 5.0 \%$, and $7.5 \%)$ to know the properties if to be used at hot and region. III. RESULTS AND DISCUSSIONS

The aim of this study was to achieve the viability of using CR as the additive material in the hot mix asphalt with a certain comparison is expected to improve the quality of the asphalt concrete.

In comparison between the two types (without and with crumb rubber) of properties of the hot mix asphalt toward the Marshall properties to get Optimum Asphalt Content, Indirect Tensile Strength (ITS) at different test temperature $\left(30^{\circ} \mathrm{C}\right.$, $40{ }^{\circ} \mathrm{C}$ and $60^{\circ} \mathrm{C}$ ) and Unconfined Compressive Strength (UCS) at $30^{\circ} \mathrm{C}$.

\section{Materials and Properties}

The main materials used for this study were: asphalt AC 60/70, coarse aggregate, fine aggregate. All properties of the materials used were measured for further analysis consideration. Several tests were conducted in order to measure their properties according to the specifications referred that were AASHTO and Bina Marga Standard.

\section{Aggregate}

The aggregate used as the materials for the split mastic asphalt mix. Base on the properties test of coarse aggregate and fine aggregate result as Table 1 and Table 2 as folows: ${ }^{[1]}$

Table 1: Result Properties Test Fine Aggregate

\begin{tabular}{|c|c|c|c|}
\hline No & Properties & $\begin{array}{c}\text { Result Fine } \\
\text { aggregate }\end{array}$ & $\begin{array}{c}\text { Specification } \\
\text { (Bina Marga } \text { ) }\end{array}$ \\
\hline $\mathbf{1}$ & Bulk specific gravity of fine aggregate & 2.52 & $\geq 2.5$ \\
\hline $\mathbf{2}$ & SSD specific gravity of fine aggregate & 2.59 & $\geq 2.5$ \\
\hline $\mathbf{3}$ & $\begin{array}{c}\text { Apparent specific gravity of fine } \\
\text { aggregate }\end{array}$ & 2.723 & $\geq 2.5$ \\
\hline $\mathbf{4}$ & Water absorption of fine aggregate & 2.94 & $\leq 3$ \\
\hline
\end{tabular}

Table 2: Result Properties Test Aggregate ${ }^{[2]}$ 


\begin{tabular}{|c|c|c|c|}
\hline No & Properties & Result & $\begin{array}{c}\text { Specification } \\
\text { (Bina Marga) }\end{array}$ \\
\hline $\mathbf{1}$ & Bulk specific gravity of coarse aggregate & 2.64 & $\geq 2.5$ \\
\hline $\mathbf{2}$ & SSD specific gravity of coarse aggregate & 2.67 & $\geq 2.5$ \\
\hline $\mathbf{3}$ & Apparent specific gravity of coarse aggregate & 2.714 & $\geq 2.5$ \\
\hline $\mathbf{4}$ & Water absorption of coarse aggregate & 1.02 & $\leq 3$ \\
\hline $\mathbf{5}$ & Abrasion & 21.31 & $\leq 40$ \\
\hline $\mathbf{6}$ & Adhesiveness & 99 & $\geq 95$ \\
\hline
\end{tabular}

\section{Asphalt}

The properties test of asphalt AC60/70 produced by PT. PERTAMINA. Table 3 presents the results of properties test asphalt AC60/70. ${ }^{[3,4]}$

Table 3: Result Properties Test of Asphalt AC 60/70

\begin{tabular}{llcc}
\hline No & \multicolumn{1}{c}{ Characteristics } & Result & $\begin{array}{c}\text { Specification } \\
\text { (Bina Marga |) }\end{array}$ \\
\hline $\mathbf{1}$ & Specific gravity of asphalt & 1.045 & Min.1 \\
$\mathbf{2}$ & Penetration (mm) & 63.5 & $60-79$ \\
$\mathbf{3}$ & Ductility (cm) & 164 & Min. 100 \\
$\mathbf{4}$ & Flash point and fire point @ & $320-326$ & Min. 200 \\
$\mathbf{5}$ & Softening point (c) & 48.35 & $48-58$ \\
$\mathbf{6}$ & Asphalt solubility in TCE (tri chlore & 99.59 & MIN .99 \\
& enthelyn )/CCL & & \\
\hline
\end{tabular}

\section{Marshall Test of Asphalt concrete (AC 60/70)}

The Marshall method uses standard test specimens of $64 \mathrm{~mm}$ thick $\times 100 \mathrm{~mm}$ diameter. These were prepared using a specified procedure for heating, mixing and compacting the asphalt aggregate mixes Marshall Test for the asphalt concrete (AC 60/70 without crumb rubber) within the range given $(5 \%$, $5.5 \%, 6.0 \%, 6.5 \%$ and $7.0 \%$ ). The optimum bitumen content $(\mathrm{OBC})$ has been determined in this study based on the maximum stability according to the Marshall Stability (MS). Table 4 shows some properties of the 60/70 (Asphalt concrete without crumb rubber) with differt tempterure $30 \mathrm{oC}, 40 \mathrm{oC}$ and $60 \mathrm{oC}$. After that will get rsult of stablaity,Flow, Void Filled With Asphalt (VFWA) and Marshall quotient (MQ), Void in the aggregate (VMA) and air void .

Table 4: Properties of asphalt concrete without crumb rubber $(60 / 70)$

\begin{tabular}{ccccccccc}
\hline No & $\begin{array}{c}\text { Bitumen } \\
\text { Content } \\
(\%)\end{array}$ & $\begin{array}{c}\text { Stabilities } \\
\text { Kg }\end{array}$ & $\begin{array}{c}\text { Flow } \\
(\mathbf{m m})\end{array}$ & VFWA & $\begin{array}{c}\text { Air } \\
\text { void }\end{array}$ & MQ & Density & VMA \\
\hline $\mathbf{1}$ & 5.0 & 1035.33 & 2.80 & 61.44 & 6.91 & 369.85 & 2.29 & 17.92 \\
$\mathbf{2}$ & 5.5 & 1336.90 & 3.22 & 66.89 & 6.14 & 415.72 & 2.29 & 18.26 \\
$\mathbf{3}$ & 6.0 & 1412.80 & 3.40 & 70.31 & 5.59 & 415.02 & 2.29 & 18.79 \\
\hline $\mathbf{4}$ & 6.5 & 1328.01 & 3.17 & 75.92 & 4.65 & 418.29 & 2.30 & 19.00 \\
$\mathbf{5}$ & 7.0 & 1166.02 & 2.67 & 80.60 & 3.73 & 441.71 & 2.30 & 19.22 \\
\hline
\end{tabular}

This relationship between the stability and the asphalt content is shown in Figure 1.

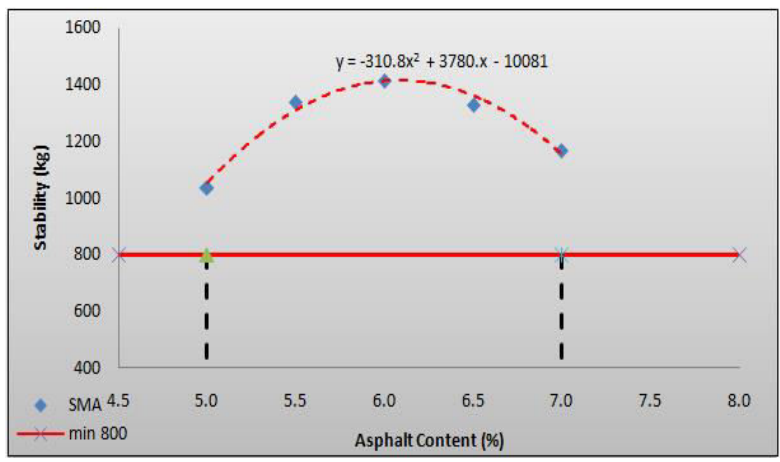

Figure 1: Ccorrelation between Stability and Asphalt Content (\%) without CR

The following observations obtained that the stability value of asphalt concrete without crumb rubber is optimum with asphalt content $6.0 \%$ by $1412.80 \mathrm{~kg}$. Thus it can be concluded that the higher the asphalt content decreases stability. The addition of asphalt content will give the higher penetration or softer. As a result, the mixture becomes more flaccid to contribute to the decrease in the value of stability. As a result, the mixture becomes more flaccid so as to contribute to the decrease in the value of stability.

This relationship between the flows and the asphalt content is shown in Figure 2.

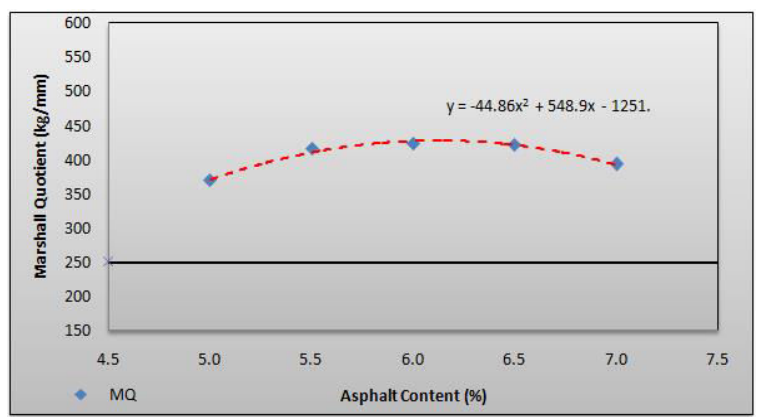

Figure 2: Correlation between MQ and Asphalt Content(\%) without CR

The following observations obtained that the flow value of asphalt concrete without crumb rubber is optimum with asphalt content $6 \%$ by $3.40 \mathrm{~mm}$.

Asphalt content increases flow. With The addition of the asphalt content will affect the mixes become more flexible and the resistance to deformation decreases resulting in a high flow value. ${ }^{[10]}$

This relationship between the Marshall quotients and asphalt content is shown in Figure 3. toward asphalt content.

Through the review of the marshal quotient test result in Table 4. and Figure (2) were obtained the following observations that the marshal quotient value of asphalt concrete without crumb rubber is highest with asphalt content $6.0 \%$ by 423.06 
$\mathrm{kg} / \mathrm{mm}$ and is smallest with asphalt content $5 \%$ by $369.85 \mathrm{~kg} / \mathrm{mm}$. Thus it can be concluded that the higher the asphalt content decreases marshal quotient.

\section{The Influence of CR Additive on the Properties} of $\mathrm{AC}$

Marshall Test for the asphalt concrete with crumb rubber within the range given $2.5 \%, 5.0 \%, 7.5 \%$, and $10 \%$. The OBC has been determined in the study based on the maximum stability according to the MS. It generally occupies $60 \%$ to $75 \%$ of the concrete volume

A. Properties of Asphalt Concrete With 2.5\% Crumb Rubber

Table 5: shows some properties of asphalt concrete modified with crumb rubber $2.5 \%$

Table 5: Properties of asphalt concrete with $2.5 \%$ crumb rubber $(60 / 70)$

\begin{tabular}{cccccccc}
\hline $\begin{array}{c}\text { Asphalt } \\
\text { Content } \\
(\%)\end{array}$ & $\begin{array}{c}\text { Stabilities } \\
\mathrm{Kg}\end{array}$ & $\begin{array}{c}\text { Flow } \\
\mathrm{mm}\end{array}$ & VFWI & $\begin{array}{c}\text { Air } \\
\text { voids }\end{array}$ & III & Density & VIIA \\
\hline 5.0 & 896.78 & 3.00 & 59.96 & 7.37 & 299.28 & 2.28 & 18.33 \\
\hline 5.5 & 1056.50 & 3.53 & 67.97 & 5.77 & 300.22 & 2.30 & 17.94 \\
6.0 & 1181.26 & 3.80 & 71.41 & 5.32 & 311.34 & 2.30 & 18.57 \\
\hline 6.5 & 1172.59 & 3.47 & 74.99 & 4.79 & 339.50 & 2.29 & 19.12 \\
7.0 & 1029.50 & 2.80 & 82.82 & 3.23 & 367.41 & 2.31 & 18.81 \\
\hline
\end{tabular}

This relationship between the stability and the asphalt content with CR $2.5 \%$ is shown in Figure 3.

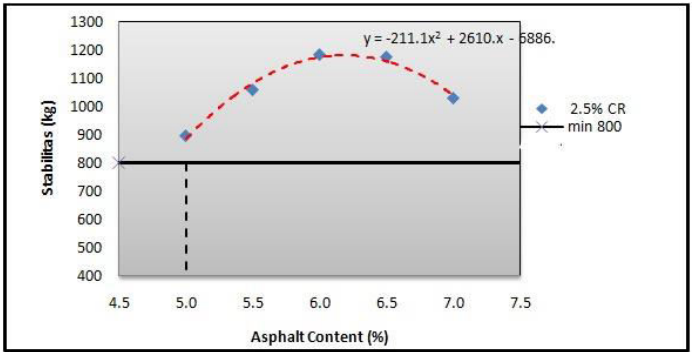

Figure 3: Correlation stability and Asphalt Content $(\%)$ with $2.5 \% \mathrm{CR}$ toward asphalt content

Through the review of the stability test results in Table 3: and Figure 3: were obtained the following observations that the highest stability value of asphalt concrete without crumb rubber is asphalt content $6.0 \%$ by $1412.80 \mathrm{~kg}$ and the smallest stability is asphalt content $5.0 \%$ by 1035.33 and $7.0 \%$ by $1166.02 \mathrm{~kg}$. Thus it can be concluded that the higher percent and smaller percent of the asphalt content decreases stability. Thus addition of asphalt content will give the higher penetration or softer. As a result, the mixture becomes more flaccid so as to contribute to the decrease in the value of stability. ${ }^{[15]}$
This relationship between the flows and the asphalt content is shown in Figure.4:

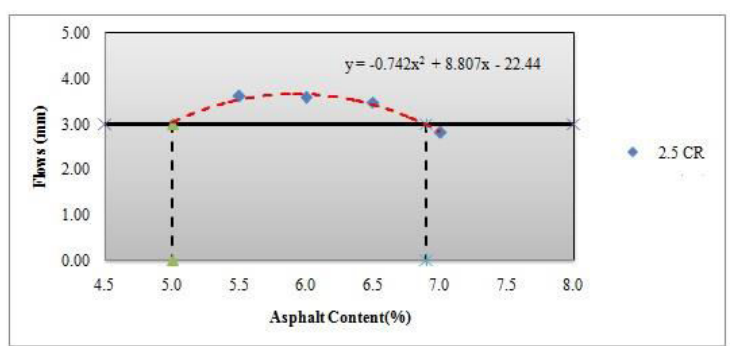

Figure 4: Correlation flows and Asphalt Content(\%) without CR toward asphalt content

Through the review of the flow test results in Table (4.5) and Figure (4.10) were obtained the following observations that flow value of asphalt concrete with crumb rubber $2.5 \%$ is highest with asphalt content $6.0 \%$ by $3.80 \mathrm{~mm}$ and smallest with asphalt content $7.0 \%$ by $2.8 \mathrm{~mm}$. Thus it can be concluded that the higher the asphalt content increases flow. With the addition of the asphalt content will affect the mixes become less flexible and the resistance to deformation decreases resulting in a high flow value. ${ }^{[14]}$

This relationship between the Marshall quotients and the asphalt content with CR $2.5 \%$ is shown in Figure 5:

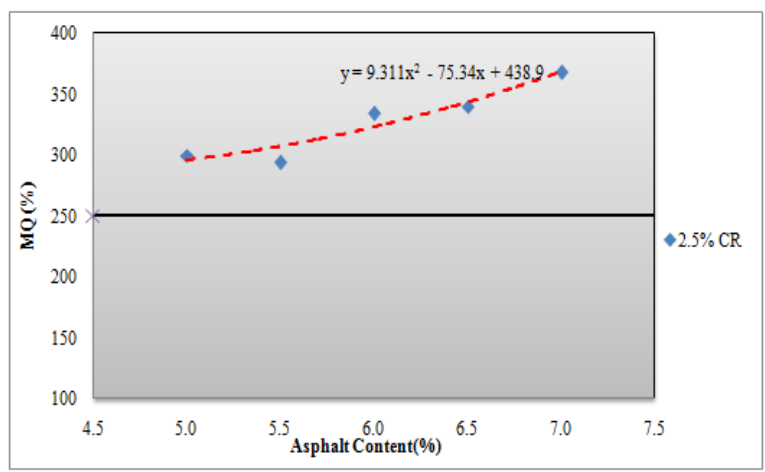

Figure 5: Correlation $\mathrm{MQ}(\mathrm{kg} / \mathrm{mm})$ and Asphalt Content (\%) without CR toward asphalt content

\section{Comparison of Marshall Test}

\section{A. Stability}

Table.6. Stability (kg) of AC modified with and without crumb rubber

\begin{tabular}{cccccc} 
Asphalt & Stability & Stability & Stability & Stability & Stability \\
Content & 0\% CR & $2.5 \%$ CR & $5.0 \%$ CR & $7.5 \%$ CR & $10 \%$ CR \\
\hline 5.00 & 1035.33 & 896.78 & 784.31 & 747.51 & 731.87 \\
5.50 & 1336.90 & 1056.50 & 883.42 & 884.20 & 760.38 \\
6.00 & 1412.80 & 1181.26 & 962.00 & 901.33 & 774.43 \\
6.50 & 1328.01 & 1172.59 & 921.08 & 900.28 & 718.15 \\
7.00 & 11660.02 & 1029.50 & 846.48 & 809.21 & 649.58 \\
\hline
\end{tabular}




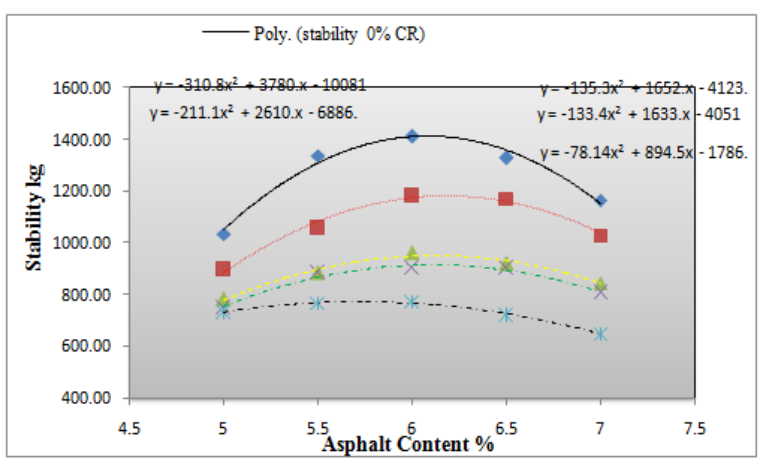

Figure .6.Comparison of flow test for Asphalt Content $(\%)$ with and without CR

Through the comparison of the stability test results in Table 6 and Figure 6 it was obtained that the asphalt concrete without crumb rubber with asphalt content $6 \%$ has optimum stability value of 1412.80 $\mathrm{kg}$. On the other hand, AC modified with $2.5 \% \mathrm{CR}$ has optimum stability value of $1181.26 \mathrm{~kg}$ at $6.0 \%$ asphalt content; AC modified with $5 \% \mathrm{CR}$ has optimum stability value of $962.0 \mathrm{~kg}$ at $6.5 \%$ asphalt content. AC modified with $7.5 \% \mathrm{CR}$ has optimum stability value of $901.33 \mathrm{~kg}$ at $6.0 \%$ asphalt content. AC modified with $10 \% \mathrm{CR}$ has optimum stability value of $769.38 \mathrm{~kg}$ at $5.5 \%$ asphalt content. Thus it can be concluded that the higher crumb rubber percent decreases stability. Further injection of crumb rubber into the mixture led to a decrease in the value of stability because application of excessive crumb rubber decreases the coarse aggregate contact point within the mixture.. As a result, the mixture becomes more flaccid so as to contribute to the decrease in the value of stability ${ }^{[26]}$. Low stability suggests low quality of aggregates. The stability of aggregates decreases with an increase in crumb rubber content ${ }^{[22,]}$. It was found that increasing the crumb rubber reduces the stability of $\mathrm{AC}$, with higher percent of crumb rubber yielding in lowest stability value. However, it was reported that crumb rubber has more effect on performance of asphalt mixture by increasing the Marshal Stability and Flow ${ }^{[16]}$.

\section{B. Flows}

Table.7. Flow $(\mathrm{mm})$ of AC modified with crumb rubber

\begin{tabular}{cccccc}
$\begin{array}{c}\text { Asphalt } \\
\text { Content }\end{array}$ & $\begin{array}{c}\text { Flow } \\
\text { 0\%CR }\end{array}$ & $\begin{array}{c}\text { Flow } \\
\mathbf{2 . 5 \% C R}\end{array}$ & $\begin{array}{c}\text { Flow5.0\% } \\
\text { CR }\end{array}$ & $\begin{array}{c}\text { Flow 7.5\% } \\
\text { CR }\end{array}$ & $\begin{array}{c}\text { Flow 10\% } \\
\text { CR }\end{array}$ \\
& & & & & \\
$\mathbf{5 . 0 0}$ & 2.80 & 3.00 & 4.00 & 4.37 & 5.03 \\
$\mathbf{5 . 5 0}$ & 3.22 & 3.53 & 4.13 & 4.80 & 5.03 \\
\hline $\mathbf{6 . 0 0}$ & 3.40 & 3.80 & 3.97 & 5.17 & 5.35 \\
$\mathbf{6 . 5 0}$ & 3.17 & 3.47 & 3.60 & 4.61 & 5.13 \\
\hline $\mathbf{7 . 0 0}$ & 2.67 & 2.80 & 2.80 & 3.73 & 6.13 \\
\hline
\end{tabular}

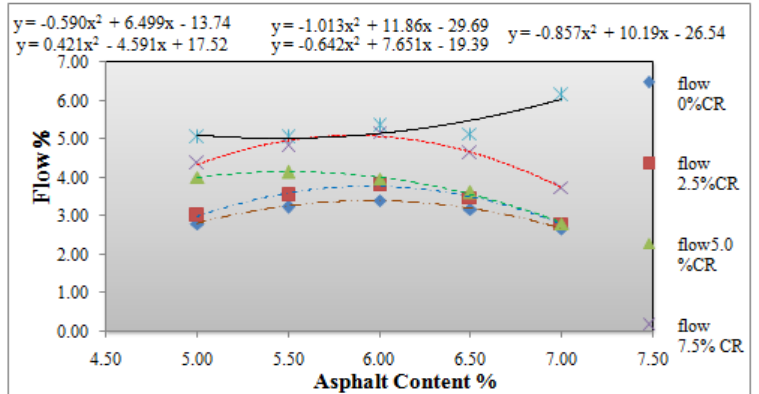

Figure .7.Comparison of flow test for Asphalt Content(\%) with and without $\mathrm{CR}$

Through the comparison of the Flows test results in Table 7 Figure 7 it was found that flow test value of asphalt concrete increased as the crumb rubber content increased from $0 \%$ to $7 \mathrm{CRM}$ in the mixture, which leads to a more flexible mixture.

Thus it can be concluded that the higher the crumb rubber content increased flow but higher asphalt content decreases flow. With the addition of the asphalt content the mixes become more flexible and the resistance to deformation decreases resulting in a high flow value. rubber content is reached.

\section{C.Void Filled With Asphalt (VFWA)}

The analysis of the VFWA test results in Figure 8 showed that modified with $0 \%, 2.5 \%, 5.0 \%, 7.5 \%$ and $10 \% \mathrm{CR}$ have maximum VFWA values of $80.60,82.82,73.37,93.10$, and $56.94 \%$, respectively. Thus it can be concluded that increase in percent of crumb rubber content increases the VFWA. The reason is that voids provide spaces for the movement of the asphalt cement or asphalt rubber binder within the compacted mix. Mix design of asphalt and rubberized $\mathrm{AC}$ asphalt paving mixes is a trade-off between high binder content to enhance long term durability and performance, and sufficient in-place void space to avoid rutting, instability, flushing and bleeding, as it is clearly shown in Table 4.11 the VFWA.

Table 8.VFWA(\%) of AC modified with crumb rubber

\begin{tabular}{cccccc}
$\begin{array}{c}\text { Asphalt } \\
\text { Content }\end{array}$ & VFWA & VFWA & VFWA & VFWA & VFWA \\
& & $\mathbf{2 . 5 \% C R}$ & $\mathbf{5 . 0 \% C R}$ & $\mathbf{7 . 5 \%} \mathbf{C R}$ & $\mathbf{1 0 \%} \mathbf{C R}$ \\
$\mathbf{5 . 0 0}$ & 61.44 & 59.96 & 54.60 & 58.44 & 46.82 \\
$\mathbf{5 . 5 0}$ & 66.89 & 67.97 & 59.63 & 64.05 & 49.94 \\
\hline $\mathbf{6 . 0 0}$ & 70.31 & 71.41 & 65.84 & 70.79 & 56.41 \\
$\mathbf{6 . 5 0}$ & 75.92 & 74.99 & 70.68 & 79.92 & 57.26 \\
\hline $\mathbf{7 . 0 0}$ & 80.60 & 82.82 & 73.37 & 93.10 & 56.94 \\
\hline
\end{tabular}




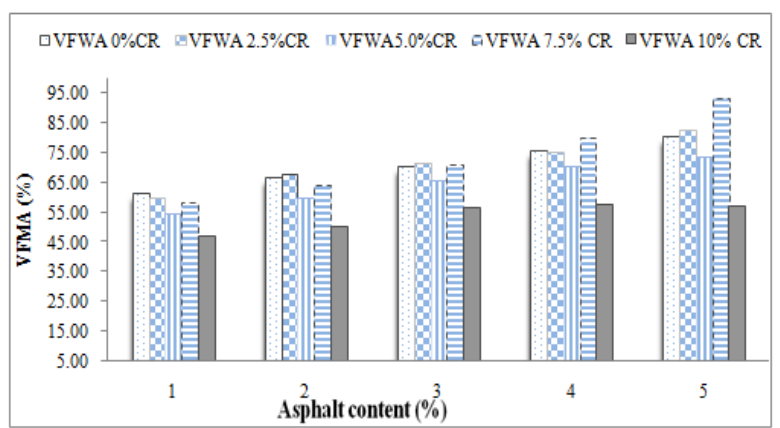

Figure. 8 Comparison of VFWE(\%) test for Asphalt Content $(\%) \mathrm{AC}$ with and without $\mathrm{CR}$

\section{D.Voids in Mix (VIM) Test}

Through the comparison of the Voids In Mix test results in Table.12 Figure 9it was found that the Voids in Mix value of asphalt concrete without crumb rubbers is 6.91 at asphalt content $5 \%$, while AC modified with $2.5 \%, 5.0 \%, 7.5 \%$, and $10 \%$ CR have maximum Voids In Mix value of 7.37, 8.96, 7.78 and $11.84 \%$, respectively asphalt content $5 \%$. Thus it can be concluded that higher crumb rubber and asphalt content increase Voids in Mix. This is supported previous study that found that crumb rubber particle size can affect the optimum binder content for open graded friction course. The durability of HMA is a function of the VIM or porosity. In general, the higher the porosity, the less permeable will be the mixture and vice versa. Too much voids in the mix (high porosity) will provide passageways through the mix for the entrance of damaging air and water. Too low porosity could lead to flushing where the excess bitumen squeezes out of the mix to the surface. ${ }^{[12,17]}$

Table .9.VIM(\%) of AC modified with crumb rubber

\begin{tabular}{cccccc} 
Asphalt & VIM & VIM & VIM & VIM & VIM 10\% \\
Content & 0\%CR & $\mathbf{2 . 5 \%}$ CR & $\mathbf{5 . 0 \%} \%$ & $\mathbf{7 . 5 \%}$ CR & CR \\
$\mathbf{5 . 0 0}$ & 6.91 & 7.37 & 8.96 & 7.78 & 11.84 \\
$\mathbf{5 . 5 0}$ & 6.14 & 5.77 & 8.04 & 6.79 & 11.46 \\
\hline $\mathbf{6 . 0 0}$ & 5.59 & 5.32 & 6.82 & 5.46 & 9.77 \\
$\mathbf{6 . 5 0}$ & 4.65 & 4.79 & 5.98 & 3.64 & 10.10 \\
\hline $\mathbf{7 . 0 0}$ & 3.73 & 3.23 & 5.53 & 1.18 & 11.02 \\
\hline
\end{tabular}

This relationship between VIM of the asphalt concrete AC and asphalt concrete modified with crumb rubber is shown in figure 9

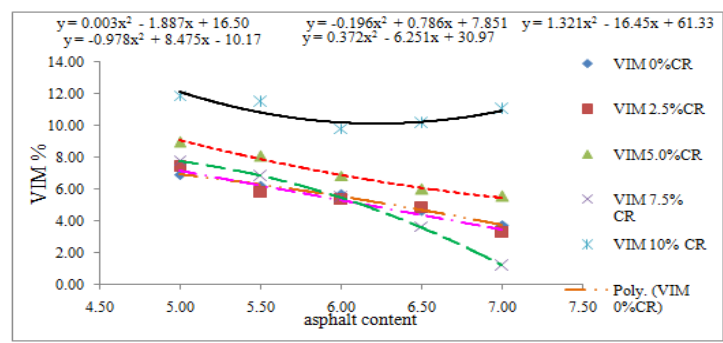

Figure 9. Comparison of VIM test for Asphalt Content $(\%)$ with and without CR

\section{Indirect Tensile Strength Test (ITS)}

The strength test was used to determine tensile strength and strain of the mixture specimens. Specimens were monotonically loaded to failure along the vertical diametric axis at the constant rate of $3 \mathrm{in} / \mathrm{min}(76.2 \mathrm{~mm} / \mathrm{min})$

The indirect tensile strength test is one type of tensile strength test used for stabilized materials.(CRMA) This test involves loading a cylindrical specimen with a compressive load along two opposite generators. This results in a relatively uniform tensile stress acting perpendicular to and along the demurral plan of the applied load this result in splitting failure generally occurring along the diametric plans three samples for each type of asphalt concrete without and with $\mathrm{CR}$ were tested at temperatures $30^{\circ} \mathrm{C}, 40^{\circ} \mathrm{C}$ and $60^{\circ} \mathrm{C} .^{[18,19]}$

Figure 10 and Table 10 shows the summarized result of indirect tensile strength test each type of asphalt concrete without and with crumb rubber in $\mathrm{OBC}$.

Table .10 Results of indirect tensile strength test(Mpa) at $\mathrm{OBC}$

\begin{tabular}{|c|c|c|c|}
\hline ACtype & ITS (a)30 C (.Mpa) & ITS @ $40 C(\mathrm{Mpa})$ & IIS @ 60C (.Mpa) \\
\hline without CR & 242.23 & 117.81 & 42.40 \\
\hline with CR 2.5\% & 144.45 & 76.03 & 17.31 \\
\hline with CR $5.0 \%$ & 129.10 & 52.84 & 10.95 \\
\hline with CR $7.5 \%$ & 100.21 & 43.55 & 9.89 \\
\hline
\end{tabular}

This relationship between the ITS and the different temperatures is shown in Figure 10.

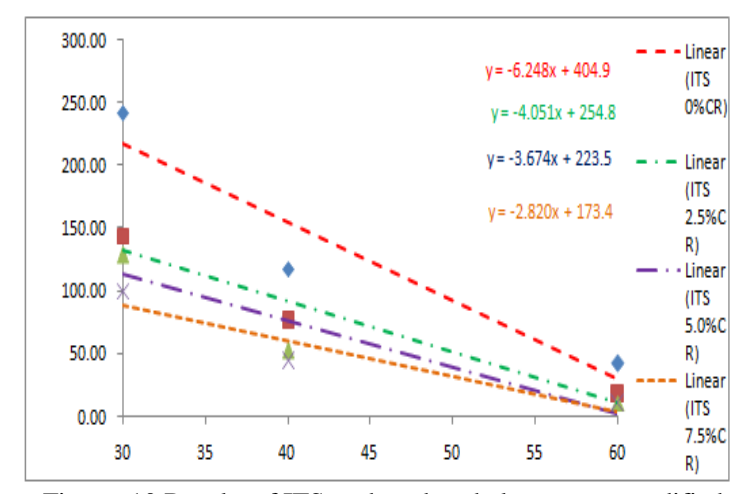

Figure .10 Results of ITS each and asphalt concrete modified without and with CR

3.Unconfined Compressive Strength Test (UCS) This test used to determine the resistance to permanent deformation of bitumen mixture at $30^{\circ} \mathrm{C}$ and loads. It is conducted by applying a static load to a specimen using optimum bitumen content (OBC) and then measuring the maximum load. This test used to determine the permanent 
deformation of asphalt concrete without crumb rubber and asphalt concrete with three type crumb rubber is done using UTM (Universal Testing Machine) to obtained strong push by the unit KN, and then a strong press is made to the calculation unit $\mathrm{Kpa}^{[20]}$. The unconfined compression test is by far the most popular method of shear testing because it is one of the fastest and cheapest methods of measuring shear strength ${ }^{[21]}$. The results of the unconfined compressive strength test give at Table 11 and Figure 11.

\begin{tabular}{ccc} 
Table. 11: Results of(UCS )Kpa Unconfined compressive \\
strength test at at $30^{\circ} \mathrm{C}$ \\
Crumb Rubber & Load Kpa @ $30^{\circ} \mathrm{C}$ & OBC \\
\hline 0 & 5220.707633 & 6.4 \\
\hline 2.5 & 4097.285707 & 6.475 \\
$\mathbf{5}$ & 3234.877943 & 6.45 \\
\hline 7.5 & 2619.054288 & 6.375 \\
\hline
\end{tabular}

This relationship between the UCS and the CR is shown in Figure 11.

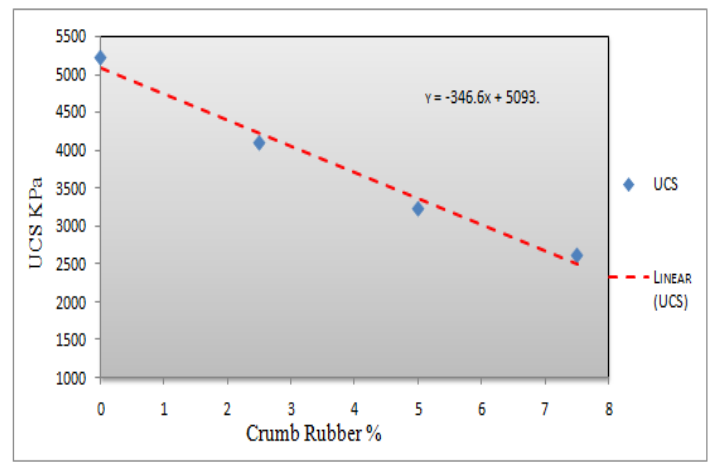

Figure 11 Results of UCS each and Asphalt concrete modified without and with $\mathrm{CR}$ at $30^{\circ} \mathrm{C}$

\section{Indirect Tensile Strength Modulus (ITSM)}

ITSM test was performed both on samples of thin normal and modified AC using UMMATTA. Tests were conducted at a temperature of $40^{\circ} \mathrm{C}$ and the results can be seen in Table 12 and Figure 12.

Table.12. Indirect Tensile Strength Modulus test at $40^{\circ} \mathrm{C}$

\begin{tabular}{ccccc} 
CR\% & \multicolumn{3}{c}{ ITSM (MPa) at $40^{\circ} \mathrm{C}$} & Average (MPa) \\
\hline $0 \%$ & 633 & 705 & 669 & 669 \\
$\mathbf{2 . 5 0} \%$ & 613 & 586 & 599.5 & 599.5 \\
$\mathbf{5 . 0 0 \%}$ & 363 & 349 & 356 & 356 \\
$\mathbf{7 . 5 0} \%$ & 194 & 234 & 214 & 214 \\
\hline
\end{tabular}

Three samples were tested for each unmodified and modified mixture. To obtain a stiffness modulus for a mixture, each sample was tested in three different conditions and the average value was adopted.
Stiffness modulus of the mixtures is shown in Table 12 Figure 12.

This relationship between the ITSM and the CR is shown in Figure 12

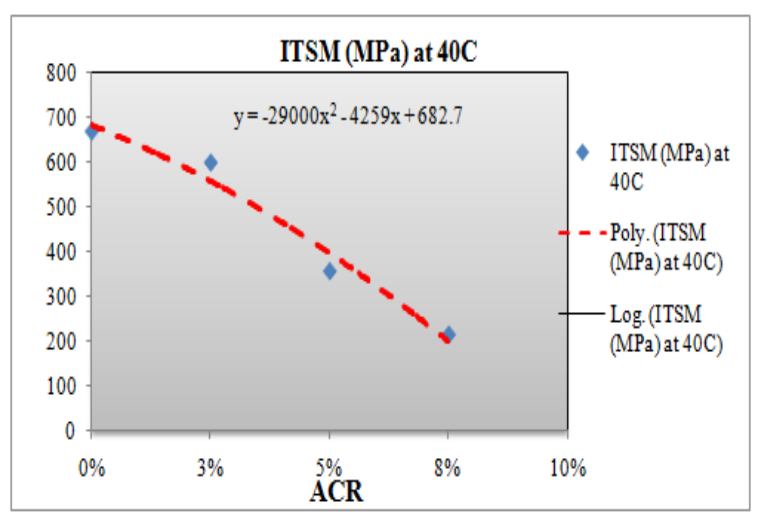

Figure 12: results of ITSM each and Asphalt concrete modified without and with CR

\section{Permeability Test $(\mathbf{M})$}

Permeability testing is important because one of the primary assumptions is structural pavement design for conventional pavement is flexible (asphalt concrete) and the pavement must be impermeable. The basis for this design approach is to minimize moisture infiltration and thus maintain adequate support from the underlying unbound materials. $^{[24,25]}$

Table 13 shows the result of permeability test at OBC and Figure 13 and Figure 14 shows the summarized results for the each type of asphalt concrete at OBC.

Through the review of the permeability test results in Table 13 and Figure 13 and 4.42 Were obtained the following observations that the coefficient of permeability $(\mathrm{K})$ value of $\mathrm{AC}$ with crumb rubber $7.5 \%$ is higher than asphalt concrete without crumb rubber (original) and with crumb rubber $2.5 \%$ and $5.0 \%$ by $9.24 \mathrm{E}-07 \mathrm{dyen} / \mathrm{cm}^{2}$ at water pressure 10000 dyen $/ \mathrm{cm}^{2}$ and by $9.2 .57 \mathrm{E}-06 \mathrm{dyen} / \mathrm{cm}^{2}$ at water pressure 20000 dyne $/ \mathrm{cm}^{2}$

The results of permeability test shows that asphalt concrete without crumb rubber lower than $\mathrm{AC}$ with crumb rubber. Since the mixture has the lowest coefficient of permeability the higher quality, because, when water leaks into the soil layer (base course), causing deformities, cracks, and holes observed. ${ }^{[22,23]}$

That the relationship between the coefficient of permeability and water pressure to be an inverse relationship, because the increase of water pressure leads to a decrease in permeability coefficient. 
Table 13: Results of Permeability Test at OBC.

\begin{tabular}{|c|c|c|c|c|c|c|c|}
\hline \multirow{2}{*}{$\begin{array}{c}\text { Crumb } \\
\text { Rubber } \\
\%\end{array}$} & \multirow[t]{2}{*}{$\begin{array}{l}\text { Asphalt } \\
\text { Content }\end{array}$} & \multirow{2}{*}{$\begin{array}{l}\text { Height } \\
(\mathrm{L}) \\
(\mathrm{cm})\end{array}$} & \multirow[t]{2}{*}{$\begin{array}{l}\text { Area (A) } \\
(\mathrm{cm} 2)\end{array}$} & \multicolumn{2}{|c|}{$\begin{array}{l}\text { Pressure Water } 10000 \\
\text { dyne } / \mathrm{cm}\end{array}$} & \multicolumn{2}{|c|}{$\begin{array}{l}\text { Pressure Water } \\
20000 \text { dyne/cm }\end{array}$} \\
\hline & & & & $\begin{array}{l}\text { Time }(\mathrm{T}) \\
\mathrm{sec}\end{array}$ & $\begin{array}{l}\text { Permeability } \\
(\mathrm{K}) \mathrm{cm} / \mathrm{sec}\end{array}$ & $\begin{array}{l}\text { Time } \\
\text { (T) } \mathrm{sec}\end{array}$ & $\begin{array}{l}\text { Permeability } \\
(\mathrm{K}) \mathrm{cm} / \mathrm{sec}\end{array}$ \\
\hline \multirow[t]{4}{*}{0} & 6.4 & 6.127 & 79.756 & 194 & $3.96 \mathrm{E}-07$ & 60.2 & $6.38 \mathrm{E}-08$ \\
\hline & 6.4 & 6.131 & 79.756 & 207 & $3.71 \mathrm{E}-07$ & 73 & $5.27 \mathrm{E}-08$ \\
\hline & 6.4 & 6.129 & 79.756 & 201 & $3.82 \mathrm{E}-07$ & 75 & $5.12 \mathrm{E}-08$ \\
\hline & & \multicolumn{3}{|c|}{ Average } & $3.83 \mathrm{E}-07$ & & $5.59 \mathrm{E}-08$ \\
\hline \multirow[t]{4}{*}{2.5} & 6.475 & 6.383 & 79.756 & 202 & $3.96 \mathrm{E}-07$ & 61 & $6.56 \mathrm{E}-08$ \\
\hline & 6.475 & 6.41 & 79.756 & 106 & $7.58 \mathrm{E}-07$ & 35 & $1.15 \mathrm{E}-07$ \\
\hline & 6.475 & 6.3965 & 79.756 & 135 & $5.94 \mathrm{E}-07$ & 60.2 & $6.66 \mathrm{E}-08$ \\
\hline & & \multicolumn{3}{|c|}{ Average } & $5.83 \mathrm{E}-07$ & & $8.23 \mathrm{E}-08$ \\
\hline \multirow[t]{4}{*}{5} & 6.45 & 6.408 & 79.756 & 160 & $5.02 \mathrm{E}-07$ & 31 & $1.3 \mathrm{E}-07$ \\
\hline & 6.45 & 6.544 & 79.756 & 113 & $7.26 \mathrm{E}-07$ & 58 & $7.07 \mathrm{E}-08$ \\
\hline & 6.45 & 6.476 & 79.756 & 143 & $5.68 \mathrm{E}-07$ & 46 & $8.83 \mathrm{E}-08$ \\
\hline & & \multicolumn{3}{|c|}{ Average } & $5.99 \mathrm{E}-07$ & & $9.62 \mathrm{E}-08$ \\
\hline \multirow[t]{4}{*}{7.5} & 6.375 & 6.621 & 79.756 & 81 & $1.02 \mathrm{E}-06$ & 30 & $1.38 \mathrm{E}-07$ \\
\hline & 6.375 & 6.56 & 79.756 & 97 & $8.48 \mathrm{E}-07$ & 32 & $1.29 \mathrm{E}-07$ \\
\hline & 6.375 & 6.5905 & 79.756 & 92 & $8.98 \mathrm{E}-07$ & 35 & $1.18 \mathrm{E}-07$ \\
\hline & & \multicolumn{3}{|c|}{ Average } & $9.24 \mathrm{E}-07$ & & $1.28 \mathrm{E}-07$ \\
\hline
\end{tabular}

Figure 13: The results of permeability test at 10000 dyen/cm 2

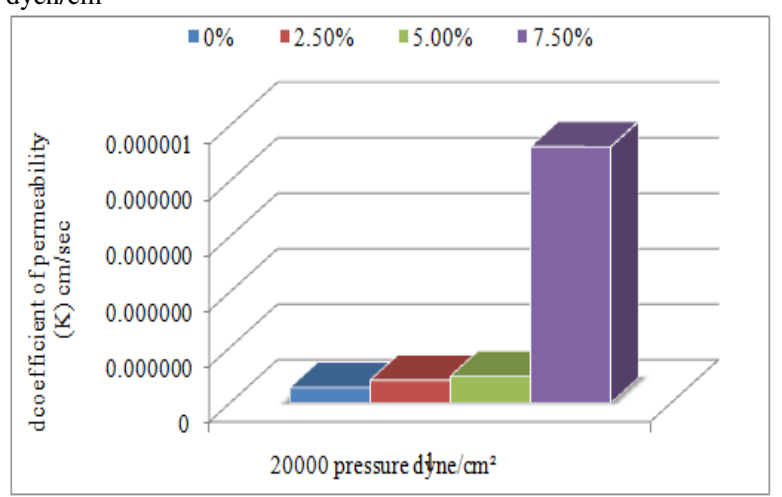

Figure 14: The results of permeability test at 20000 dyen $/ \mathrm{cm}^{2}$ This relationship between the Permeability of the asphalt concrete AC and asphalt concrete modified with crumb rubber is shown figure 13,14 .

\section{CONCLUSION}

On the basis of the results of the laboratory test in this study, the conclusion as follows: 1.AC was modified with $0 \%, 2.5 \%, 5.0 \%, 7.5 \%$, and $10 \%$ crumb rubber, which could be used as aggregate substitute for flexible asphalt concrete at hot and arid region because it is temperature tolerant. The increase amount of crumb rubber in asphalt concrete mixture will decrease the Marshall stability. Unmodified asphalt concrete was more sensitive to temperature changes compared asphalt concrete modified with crumb rubber mixtures. The ITS, ITSM, and UCS are affected by temperature. They decrease as the temperature increases and also affected by crumb rubber composition.

2 . The increase amount of crumb rubber in asphalt concrete mixture will decrease the Marshall stability. However, this was not always followed by sufficient flow; therefore, it resulted in less flexibility, as represented by Marshall Quotient parameter. In this study, the use of $2.5 \%, 5.0 \%$, and $7.5 \%$ crumb rubber in CRM asphalt can show the best result in terms of load deformation in OBC When compared with the constants. But 10\% CRM failed result in terms of load deformation in OBC When compared with the standard and Bina Marga, (Indonesian Standard).

3. Unmodified asphalt concrete was more sensitive to temperature changes compared asphalt concrete modified with crumb rubber mixtures. The ITS, ITSM, and UCS are affected by temperature. They decrease as the temperature increases. The ITS, ITSM, and UCS are affected by crumb rubber composition. The reasons why some differences in values of ITS, ITSM, and UCS tests as compared to other research results are due to the differences in: Aggregate gradation, OBC, Asphalt type, Mix conditions, machine type, and binder content. The results of permeability test shows that the asphalt 60/70 pen without CR was less than asphalt concrete with $\mathrm{CR}$.

\section{REFERENCES}

[1] M. Hossain, S. Swartz, and E. Hoque, "Fracture and tensile Characteristics of Asphalt-Rubber Concrete," J. Mater. Civ. Eng., pp. 287-294, 1999.

[2] Indonesian Standard, "Tata Cara Pemilihan Campuran Untuk Beton Normal, Beton Berat dan Beton Massa," 2012.

[3] American Society for Testing and Materials (ASTM), "Concrete and Concrete Agregate C11735T direct responsibility of Subcommittee C09.20 on Normal Weight Aggregates," Philadelphia, 1995.

[4] P. Radziszewski, "Modified Asphalt Mixtures Resistance to Permanent Modulus of Asphalt Concrete Mixtures," J. Mater. Civ. Eng., vol. 8, no. 4, pp. 307-315, 2007.

[5] T. S. Schuler, R. D. Pavlovich, J. A. Epps, and A. C. $\mathrm{K}$, "Investigation of Materials and Structural Properties of Asphalt Rubber Paving Mixtures," 1986.

[6] T. S. Schuler, R. D. Pavlovich, J. A. Epps, and A. C. K, "Investigation of Epps, J. A. Uses of Recycled Rubber Tires in Highways - A Synthesis of Highway Practice," 1986.

[7] S. Bahuguna, V. P. Panoskaltsis, and K. D. Papoulia, "Identification and Modeling of Permanent Deformations of Asphalt Concrete," J. Eng. Mech., vol. 132, no. 3, pp. 231-239, 2006.

[8] Bina Marga, (2006), Petunjuk Pelaksanaan Lapis Aspal Beton (LASTON) Untuk Jalan Raya. Public Work Departments, Jakarta.

[9] Bina Marga, (2010), Petunjuk Pelaksanaan Lapis Aspal Beton (LASTON) Untuk Jalan Raya. Public Work Departments, Jakarta.

[10] [3]BinaMarga, (1987), Petunjuk Pelaksanaan Lapis Aspal Beton (LASTON) Untuk Jalan Raya(SKBI2.4.26.1987). Public Work Departments, PU Publisher Foundation, Jakarta..

[11] [4] Xiao, F., Amirkhanian, S. and Juang, C. H., 2007, Rutting Resistance of Rubberized Asphalt Concrete Pavements Containing Reclaimed Asphalt 
Pavement Mixtures. Journal of Materials in Civil Engineering.Vol.19(6):475-483.

[12] [5]You, Z.and Buttlar, W. G., 2004, .Discrete Element Modeling to Predict the Modulusof Asphalt Concrete Mixtures. Journal of Materials in Civil Engineering.Vol. 16(2):140-146

[13] [10]Palit, S. K., Reddy, K. S., and Pandey, B. B., 2004, Laboratory Evaluation of Crumb Rubber Modified Asphalt Mixes. Journal of Materials in Civil Engineering.16(1):45-53.

[14] [14]Seo, Y., El- Haggan, O., King, M., Lee, S. J., and Kim, Y. R., 2007, Air Void Models for the Dynamic Modulus, Fatigue Cracking, and Rutting of Asphalt Concrete. Journal of Materials in Civil Engineering.Vol.19(10):874-883.

[15] [15] Seo, Y., El- Haggan, O., King, M., Lee, S. J., and Kim, Y. R., 2007, Air Void Models for the Dynamic Modulus, Fatigue Cracking, and Rutting of Asphalt Concrete. Journal of Materials in Civil Engineering.Vol.19(10):874-883.

[16] [16] Si. Z., Little, D. N., and Lytton,R. L., 2002, Characterization of Microdamage and Healing of Asphalt Concrete Mixtures. Journal of Materials in Civil Engineering. Pp 461-470.

[17] [17] Uzan, J. 2003. Characterization of Asphalt Concrete Materials for Permanent Deformation. The International Journal of Pavement Engineering. Vol. 4 (2): pp. 77-86.

[18] [18] Van Kirk, Jack, 2000, Reduced Thickness Asphalt Rubber Coucrete Leads to Cost Effective Pavement Rehabilitation. 3050 Beacon Blvd. Suite 205 West Sacramento, CA 95691
[19] [19] Joseph Lucaand Donath Mrawira, P.E., 2005, New Measurement of Thermal Properties of Superpave Asphalt Concrete. Journal of Materials in Civil Engineering. 17(1): 72-79.

[20] [20] Zheng, L., Huo, X. S., and Yuan, Y., 2008, Strength, Modulus of Elasticity, and Brittleness Index of Rubberized Concrete.

[21] Journal of Materials in Civil Engineering.20(11):692-699.

[22] [21] Joshi Darshna B, A.K. Patel., 2013, Optimum Bitumen Content by Marshall Mix Design from DBM. Journal of Information Knowledge and Research in Civil Engineering ISSN: 0975-6744,Vol. 2, Issue 2, November 2012-October 2013.

[23] [22] Kim, H., Wagoner, M.P. and Buttlar, W. G., 2009, Rate-dependent fracture modeling of asphalt concrete using the discrete element method. Can. J. Civ. Eng. 36: 320-330.

[24] [23] Kutay, M. E. and Aydilek, A. H., 2007, Dynamic Effects on Moisture Transport in Asphalt Concrete. Journal of Transportation Engineering.133 (7): 406-414.

[25] [24]R. RichardandT. Bent, Road Engineering for Development, Spon Press, London, UK, 2nd edition, 2004.

[26] [25] Lee, S. W.,Bae, J. M., Han, S. H. and Stoffels, S.M., 2007, Evaluation of Optimum Rubblized Depth to Prevent Reflection Cracks. Journal of Transportation Engineering. Vol. 133 (6): 355-361.

[27] [26]N. S. Mashaan, The effect of crumb rubber modifier to the properties and rheological behavior of asphalt binder [M.S.thesis], University of Malaya, Kuala Lumpur, Malaysia, 2012. 